\title{
Plastochron and yield of Physalis peruviana L. grown in different environments and transplanting dates
}

\section{Plastocrono e produção de Physalis peruviana L. cultivado em ambientes e épocas de transplantio}

\author{
André Ricardo Zeist ${ }^{1 *}$; Juliano Tadeu Vilela de Resende ${ }^{2}$; Daniel Suek Zanin ${ }^{3}$; \\ Israel Felipe Lustosa da Silva ${ }^{4}$; Daniel Fernandes da Silva ${ }^{5}$; Cleber Maus Alberto ${ }^{6}$; \\ André Gabriel ${ }^{4}$; Jair Garcia Neto ${ }^{7}$
}

\section{Highlights:}

The growth of Physalis peruviana is influenced by temperature.

The plastochron value for $P$. peruviana differs between the vegetative and productive period.

Greenhouse provides greater growth and development of $P$. peruviana.

P. peruviana seedlings should be planted until December.

\begin{abstract}
This study aimed to estimate plastochron, leaf area, and yield of Physalis peruviana seedlings grown in different environments and transplanted on different dates. The experiment was carried out in a completely randomized design, arranged in a $2 \times 3$ factorial scheme, namely: two cultivation environments (protected and field) and three transplanting dates (10/27/2013, 12/15/2013, and $02 / 11 / 2014)$. Four replicates of eight plants were used per plot, and the four central plants composed the useful area. Based on mathematical models and temperature data, plastochron was estimated for the entire crop cycle and vegetative and reproductive phases separately. Leaf area and node number were measured, and their relationship established at the end of the study. Other variables assessed were fruit number, mass, and yield per plant. Our results showed that the higher temperatures in the protected environment anticipated phenological timings. Plastochron values of 60.0 and $16.5^{\circ} \mathrm{C}$ day ${ }^{-1}$ can be used during vegetative and reproductive stages, respectively. The protected environment increased vegetative growth and development, as well as yield of $P$. peruviana seedlings. In the Guarapuava-PR region, $P$. peruviana seedlings should be transplanted during the spring so that higher fruit yield and quality could be achieved.
\end{abstract}

Key words: Protected cultivation. Node emission. Thermal sum. Biological time.

\footnotetext{
1 Prof. Dr., Curso de Graduação em Agronomia e do Programa de Pós-Graduação em Agronomia, Universidade do Oeste Paulista, UNOESTE, Presidente Prudente, SP, Brasil. E-mail: andrezeist@unoeste.br

2 Prof. Dr., Departamento de Agronomia e do Programa de Pós-Graduação em Agronomia, PGAGRO, UEL, Universidade Estadual de Londrina, Londrina, PR, Brasil.E-mail: jvresende@uol.com.br

3 Pós-Doutorando Júnior do CNPq, UEL, Londrina, PR, Brasil. E-mail: dsuekzanin@gmail.com

4 Discentes de Doutorado do Programa de Pós-Graduação em Agronomia, Universidade Estadual do Centro-Oeste, UNICENTRO, Guarapuava, PR, Brasil. E-mail: israel.felipe30@gmail.com; andre.gb85@hotmail.com

5 Pós-Doutorando do Programa de Pós-Graduação em Agronomia, UNOESTE, Presidente Prudente, SP, Brasil. E-mail: daniel_ eafi@yahoo.com.br

${ }^{6}$ Prof. Dr., Curso de Graduação em Agronomia, Universidade Federal do Pampa, UNIPAMPA, Itaqui, RS, Brasil. E-mail: cleberalberto@unipampa.edu.br

7 Discente do Programa de Pós-Graduação em Agronomia, UNOESTE, Presidente Prudente, SP, Brasil. E-mail: jairgarcianeto@ hotmail.com

* Author for correspondence
} 
Objetivou-se com o presente estudo estimar o plastocrono, a área leaf e a produção em Physalis peruviana cultivada em ambientes e épocas de transplantio. O experimento foi realizado em delineamento experimental inteiramente casualizado, em esquema fatorial $2 \times 3$, sendo dois ambientes de cultivo (cultivo protegido e a campo) e três épocas de transplantio (27/10/2013, 15/12/2013 e 11/02/2014). Quatro repetições de oito plantas por parcela foram implantadas, utilizando-se as quatro plantas centrais para avaliação. Com base em modelos matemáticos e dados de temperatura coletados o plastocrono foi estimado para o ciclo completo e fases vegetativa e reprodutiva da cultura separadamente. A área leaf bem como o número de nós foram avaliados permitindo estabelecer uma relação entre esses dois parâmetros ao fim do trabalho. Avaliou-se também o número, massa e produção de frutos comerciais por planta. Observou-se com o estudo que a temperatura em ambiente protegido foi maior quando comparada ao campo, promovendo a antecipação do desenvolvimento dos estágios fenológicos. Durante o desenvolvimento vegetativo, pode ser utilizado valor de plastocrono de $60,0{ }^{\circ} \mathrm{C}$ dia nó ${ }^{-1} \mathrm{e}$ durante o reprodutivo de $16,5{ }^{\circ} \mathrm{C}$ dia nó ${ }^{-1}$. O ambiente protegido proporcionou maior crescimento e desenvolvimento vegetativo e produtividade de $P$. peruviana, quando comparado ao cultivo em campo. $\mathrm{O}$ transplantio de $P$. peruviana na região de Guarapuava-PR deve ser feito na primavera para garantia de maior produtividade e qualidade de frutos.

Palavras-chave: Cultivo protegido. Emissão de nós. Soma térmica. Tempo biológico.

\section{Introduction}

The genus Physalis L. belongs to the Solanaceae family and is commonly found in subtropical and temperate regions around the world (Licodiedoff, Ribani, Camlofski, \& Lenzi, 2013; Fischer, Almanza-Merchán, \& Miranda, 2014). The bestknown species of this genus is Physalis peruviana L., which is native to the Andes mountain range and recognized for its sweet fruits with high contents of vitamins $\mathrm{A}$ and $\mathrm{B}$, as well as ascorbic acid, iron, phosphorus, and soluble solids (Mendoza, Rodriguez, \& Millan, 2012; Fischer et al., 2014).

The $P$. peruviana species has good prospects for domestic and international markets, being an interesting alternative for small farmers in Central and Southern Brazil (Fischer et al., 2014). Although sales and consumption have increased worldwide, its cultivation is still quite limited, mainly due to a lack of technical information on its cropping peculiarities (Muniz et al., 2011). Thus, there is a need to gain knowledge on the best transplantation time, cultivation environment, plant adaptation, and phenological responses to improve management and production techniques.
Interactions between cultivation systems and climatic conditions can change phenological timing and hence impact crop yield (Martins et al., 2012; Tomazetti et al., 2015). Although information on $P$. peruviana crop cultivation have already been reported under field conditions (Lima, Gonçalves, Tomaz, Rufato, \& Fachinello, 2009; Lima, Gonçalves, Tomaz, Rufato, \& Fachinello, 2010; Silva, Villa, Barp, Rotili, \& Stumm, 2013), few are the studies on its cultivation in protected environments (Moura, Coutinho, Pio, Bianchini, \& Curi, 2016a; Moura et al., 2016b).

The use of plastic covers in protected cultivations enables vegetable growth and development, even when environmental conditions are limiting (Heldwein et al., 2010). Accordingly, it is relevant to compare phenological responses and productive behavior of plants under protected and field cropping conditions, which until now is the most used for $P$. peruviana cultivation.

Despite being a perennial plant, P. peruviana has been grown as annual in commercial crops (Moura et al., 2016b). Thus, knowing which time is most suitable for transplanting and forming orchards in 
the field is of great relevance for obtaining plants adapted to different edaphoclimatic conditions (Lima et al., 2010).

As crop cultivation conditions are strongly altered (Araújo et al., 2016), the use of protected cultivation for physalis production requires further studies on the most suitable time for seedling transplantation to the field.

One way to evaluate the development of a plant species in a given condition is through a phenological study. Phenological studies allow predicting some events and thus making decisions about crop management to be used (Pereira, Campelo, \& Ferronato, 2010). Among the factors that are closely related to plant development, it is worth mentioning air temperature, which drives growth and development (Liu \& Heins, 2002). Air temperature directly influences most phenological parameters, among which the number of nodes in stems stands out (Pereira et al., 2010). The number of nodes can be estimated by plastochron $\left({ }^{\circ} \mathrm{C}\right.$ day node $\left.^{-1}\right)$, which is the time interval, expressed in thermal sum, between successive node appearances in plant stems (Toebe et al., 2010; Lucas, Streck, Bortoluzzi, Trentin, \& Maldaner, 2012).

Reliable plastochron estimates enable identifying phenological behavior, verifying plant adaptation, defining more appropriate management practices, besides assisting crop zoning (Zeist et al., 2017). A plastochron index represents vegetative development in plant cycle simulation models, improving $P$. peruviana development and growth modeling.

Leaf area estimation is another parameter used in plant growth analyses. It demonstrates the potential production of carbohydrates, lipids, proteins, transpiration, and $\mathrm{CO}_{2}$ net assimilation, which show the availability of photoassimilates for reproductive organs. This parameter is especially important in determining plant growth, as leaves are the main photosynthesizing organ and, in most plants, number of leaves is directly proportional to the number of nodes in the main stem (Moraes, Santos, Wisser, \& Krupek, 2013).

In $P$. peruviana plants, flowers appear in leaf axils (nodal region) (Lagos, Valejo, Criollo, \& Muñoz, 2008), and fruit growth after fertilization is closely related to the photosynthesizing capacity of leaves. In this sense, estimating plastochron and leaf area of $P$. peruviana plants and comparing plants grown in protected areas and the field, at different transplantation times, can be fundamental information for initial growth modeling and development studies. Such information can also help improve cultivation and management techniques, thereby increasing fruit yield, mainly when fruit production is limited by climatic conditions.

Given the above observations, this study aimed to estimate plastochron, leaf area, and yield of $P$. peruviana seedling grown in different environments and at varied transplantation dates.

\section{Material and Methods}

The experiment was carried out during the season of 2013/2014, in the city of Guarapuava-PR, Brazil (2523' S, 51 ${ }^{\circ} 29^{\prime} \mathrm{W}$, and 1025-m altitude). According to Köppen's classification, the climate is humid mesothermal subtropical, with non-defined dry seasons, hot summers, and moderate winters (Wrege, Steinmetz, Reisser, \& Almeida, 2011). The soil in Guarapuava is classified as Bruno Latosol (Oxisol), with a very clayey texture (Empresa Brasileira de Pesquisa Agropecuária [EMBRAPA], 2013).

Physalis peruviana plants were organized in a completely randomized design with four replications and eight plants per plot. Crop development was observed for three transplantation times: 10/27/2013 (time 1), 12/15/2013 (time 2), and 02/11/2014 (time $3)$ and for two cultivation environments: under field conditions and in a protected environment (greenhouse). 
Before field planting, the soil was plowed and then a bed mulcher was used to prepare 1.0 $\mathrm{m}$ wide beds. The soil was also corrected and fertilized according to soil analysis and following the recommendations for tomato cultivation, for a production expectation of $20 \mathrm{tha}^{-1}$, as performed by Muniz et al. (2011). After liming and fertilization, the soil was moved and covered with a $3-\mathrm{cm}$ layer of organic compost of decayed shavings.

As a protected environment, a greenhouse $30 \mathrm{~m}$ away from the field experiment was used. It had a steel tubing metal structure, measuring $8.20 \times 8.20$ $\mathrm{x} 3.50 \mathrm{~m}$ (width $\mathrm{x}$ length $\mathrm{x}$ height) and covered with $150-\mu \mathrm{m}$ low-density polyethylene (LDPE) film. The greenhouse had an evaporative air-cooling system by an exhaust fan and running water in expanded clay, which was installed on the side of the structure.

Inside the greenhouse, seedlings were planted in $10-\mathrm{dm}^{3}$ pots containing sieved, corrected, and fertilized soil, which was brought in from the field experiment. The pots were covered with a $3-\mathrm{cm}$ layer of organic compost of shavings. For irrigation, a localized system was used using microdrippers in both environments, irrigating according to tomato water requirements and criteria for each environment.

In all experimental units, sowing was carried out in 72-cell expanded polystyrene trays containing bio-stabilized pine bark-based commercial substrate and kept in a floating type hydroponic system. Seedlings were transplanted at three times when they had from 4-5 expanded defined leaves, about 45 days after sowing. In both environments, cultivation spacing was $1.00 \mathrm{~m}$ between plants and $1.50 \mathrm{~m}$ between rows. All seedlings were trimmed to two main stems supported by a $60^{\circ}$ inclined stick and training strings set at $1.7 \mathrm{~m}$ from the ground.

During the experimental time, daily minimum (Tn) and maximum (Tx) air temperatures were measured in the field environment by an automatic weather station located in the State University of Midwest (UNICENTRO), CEDETEG Campus, 120 $m$ away from the experiment. Yet, in the greenhouse, measurements were taken daily using minimum and maximum temperature thermometers. From transplanting and throughout seedling growth and development cycle, the number of visible nodes (NN) on the two main stems was counted for the four central plants of each plot every five days. A node was considered new when it had at least defined and expanded leaf.

Plastochron was estimated for each environment and transplantation time by the inverse of the angular coefficient of the linear regression between the number of visible nodes $(\mathrm{NN})$ on the main stem and the accumulated thermal sum (aTS, ${ }^{\circ} \mathrm{C}$ day). To obtain reliable plastochron estimates, regression equations were performed as adapted from Toebe et al. (2010), considering: vegetative phase - from transplanting until the onset of flowering (TR-FL); reproductive phase - from the onset of flowering until the beginning of fruit ripening (FL-FR); and single-phase - from transplanting to the beginning of fruit ripening (TR-FR). These phases were compared by the mean standard error (MSE) for both cultivation environment and transplantation times. Flowering was defined when $50 \%$ of the plants presented at least one flower per plant. In turn, the beginning of ripening was set when at least $50 \%$ of the plants had at least one fruit at an early ripening stage.

Daily thermal sum (dTS, ${ }^{\circ} \mathrm{C}$ day) was calculated in both environments as proposed by Arnold (1960); $\mathrm{dTS}=(\mathrm{Tm}-\mathrm{Tb})$, wherein mean air temperature (Tm) was calculated by the arithmetic mean between maximum Tx and minimum Tn daily temperatures, while $\mathrm{Tb}$ is the base temperature for node emission in P. peruviana plants, below which no new leaves are emitted. We adopted a $\mathrm{Tb}$ of $6.3{ }^{\circ} \mathrm{C}$ (Salazar, Jones, Chaves, Cooman, \& Fischer, 2008) and estimated the accumulated thermal sum $\left(\mathrm{aTS},{ }^{\circ} \mathrm{C}\right.$ day) by summing daily values (aTS $=\sum$ dTS).

At the beginning of flowering and fruit ripening, two plant leaves were collected per plot, placed 
in plastic trays, and sent to the Plant Physiology/ Horticulture laboratory. Then leaf area (LA) was estimated in $\mathrm{cm}^{2}$ using a bench leaf area meter (LI-COR ${ }^{\circledR}$, LI $3100 \mathrm{C}$ model). Afterwards, the relationship between accumulated LA and NN per plant (LA/NN) was determined.

Fruits from the four central plants of each plot were harvested weekly. Only fruits within the ripening stage were collected, i.e., those with straw-colored calyx and orange epidermis. They were then evaluated for number of commercial fruits - NCF (number of harvested fruits within commercial standards), commercial fruit yield - CFY (accumulated fruit production within commercial standards, in $\mathrm{g} \mathrm{plant}^{-1}$ ), and average mass of commercial fruits - AMCF (relationship between $\mathrm{CFY}$ and $\mathrm{NCF}$, in $\mathrm{g}$ fruit $^{1}$; $\mathrm{AMCF}=\mathrm{CFY} / \mathrm{NCF}$ ).
Data were tested for normality and homogeneity and then submitted to ANOVA using individual and joint F-tests. If significant, means were compared by the Tukey's test $(p \leq 0.05)$. All statistical analyses were performed with the aid of ASSISTAT software version 7.7 (F. A. S. Silva \& Azevedo, 2016).

\section{Results and Discussion}

Table 1 shows data on the monthly minimum (Tn), maximum (Tx), and mean $(\mathrm{Tm})$ air temperatures $\left({ }^{\circ} \mathrm{C}\right)$ in the field and the protected environment, measured during $P$. peruviana development cycle, and at three transplanting times.

Table 1

Minimum (Tn), maximum (Tx) and average (Tm) monthly air temperature measured during the development cycle of $P$. peruviana grown in a field and protected environment, in three transplant dates 27/10/2013, 15/12/2013 and 11/02/2014

\begin{tabular}{lccc}
\hline Month & $\mathrm{Tn}\left({ }^{\circ} \mathrm{C}\right)$ & $\mathrm{Tx}\left({ }^{\circ} \mathrm{C}\right)$ & $\mathrm{Tm}\left({ }^{\circ} \mathrm{C}\right)$ \\
\hline & & Field & 19,5 \\
October & 9,2 & 26,8 & 19,9 \\
November & 11,4 & 31,0 & 21,6 \\
December & 11,4 & 31,0 & 22,2 \\
January & 14,2 & 30,4 & 22,1 \\
February & 13,4 & 32,4 & 20,4 \\
March & 9,2 & 28,4 & 19,2 \\
April & 9,0 & 28,8 & 22,2 \\
\hline & & 32,2 & 22,1 \\
October & 10,0 & 34,0 & 24,1 \\
November & 11,0 & 37,0 & 26,0 \\
December & 13,0 & 37,9 & 27,2 \\
January & 14,7 & 38,3 & 23,1 \\
February & 14,0 & 32,5 & 24,3 \\
March & 9,8 & 32,5 & \\
April & 10,1 & & \\
\hline
\end{tabular}


In the field, $P$. peruviana flowering and fruit ripening started respectively at 38 and 87 days for seedlings transplanted on 10/27/2013 (time 1), at 34 and 80 days for those transplanted on 12/15/2013 (time 2), and at 37 and 79 days after transplantation on 02/11/2014 (time 3). Regarding seedlings grown in the protected environment, flowering began at 36,31 , and 32 days and fruit ripening at 81,71 , and 77 days after transplanting. Thus, plants cultivated in the protected environment, transplanted on times 1,2 , and 3, respectively, showed early flowering at 2,3 , and 5 days and fruit ripening at 6,9 , and 2 days when compared to those grown in the field.

The early P. peruviana flowering and fruit ripening under the protected environment corroborates the findings of Picolotto, Pereira, Vignolo, Reisser and Antunes (2014), who verified an earlier flowering of blueberries grown under low tunnel compared to those grown in an open field. Coletti, Nienow and Calvete (2011) explained that mean temperatures rise inside protected environments, which favors plant development and may lead to earlier or larger harvests.

According to Taiz and Zeiger (2013), C3 carbonfixing plants, such as Physalis peruviana, tend to develop better at temperatures around $25^{\circ} \mathrm{C}$, with higher quantitative yield compared to $\mathrm{C} 4$ plants at temperatures up to $27{ }^{\circ} \mathrm{C}$. This is due to higher net photosynthesis rates which, in turn, increase carbon fixation. Thus, since temperatures in the protected environment remained closer to the ideal range for the species, it provided greater seedling growth compared to those in the field. Furthermore, higher mean temperatures may favor several enzymatic reactions, including those involved in photosynthesis, thus influencing plant growth under such condition.

In the field and at all transplanting times, averages of daily air thermal sum (dTS) were $14.1,15.5$, and $12.9^{\circ} \mathrm{C} \mathrm{day}^{-1}$, respectively. In the same environment and referred times, plants began flowering with accumulated thermal sums (aTS) of 474.0, 526.0, and $510.9{ }^{\circ} \mathrm{C}$ day $^{-1}$, and fruits started ripening with aTS of $1266.2,1252.8$, and 1030.1 ${ }^{\circ} \mathrm{C}$ day $^{-1}$, respectively. Meanwhile, in the protected environment, aTS averages were 17.7, 19.8, and $18.0{ }^{\circ} \mathrm{C} \mathrm{day}^{-1}$, with flowering beginning after reaching aTS of $568.7,575.9$, and $589.9{ }^{\circ} \mathrm{C}_{\text {day }}{ }^{-1}$, and ripening starts after aTS of 1400.3, 1409.0, and $1385.8^{\circ} \mathrm{C}$ day $^{-1}$, respectively (Figure 1A and 1B).

Our findings show that $P$. peruviana seedlings grown in a protected environment require a larger thermal sum to start flowering. However, the said environment provides a greater daily thermal sum, thus, regardless of transplanting time, the number of days to start flowering is smaller.

During the reproductive phase, the lowest dTS values were observed in the field on time 1 , with a minimum value of $8.5{ }^{\circ} \mathrm{C}$ day. In turn, at the same time, the other interactions between environment and transplanting time presented more favorable thermal conditions for the development of seedlings, with a higher dTS. For both development phases, the highest dTS values were recorded in the protected environment on time 2 , with a maximum of $25.0^{\circ} \mathrm{C}$ day, promoting the highest aTS $\left(1409.0{ }^{\circ} \mathrm{C}\right)$ at the end of monitoring (Figure 1A and 1B).

The average air temperature was higher in the protected environment than was in the field environment. What increased thermal accumulation and hence the early occurrence of $P$. peruviana developmental stages. In estimating plastochron in beans, Heldwein et al. (2010) also found higher mean temperatures, dTS, and aTS in protected environments when compared to the field. According to Koetz, Carvalho, Sousa and Souza (2010), one of the advantages of protected environments is the rise in temperatures, which favors faster crop development, besides reducing damages to fruits by disease and pests. 

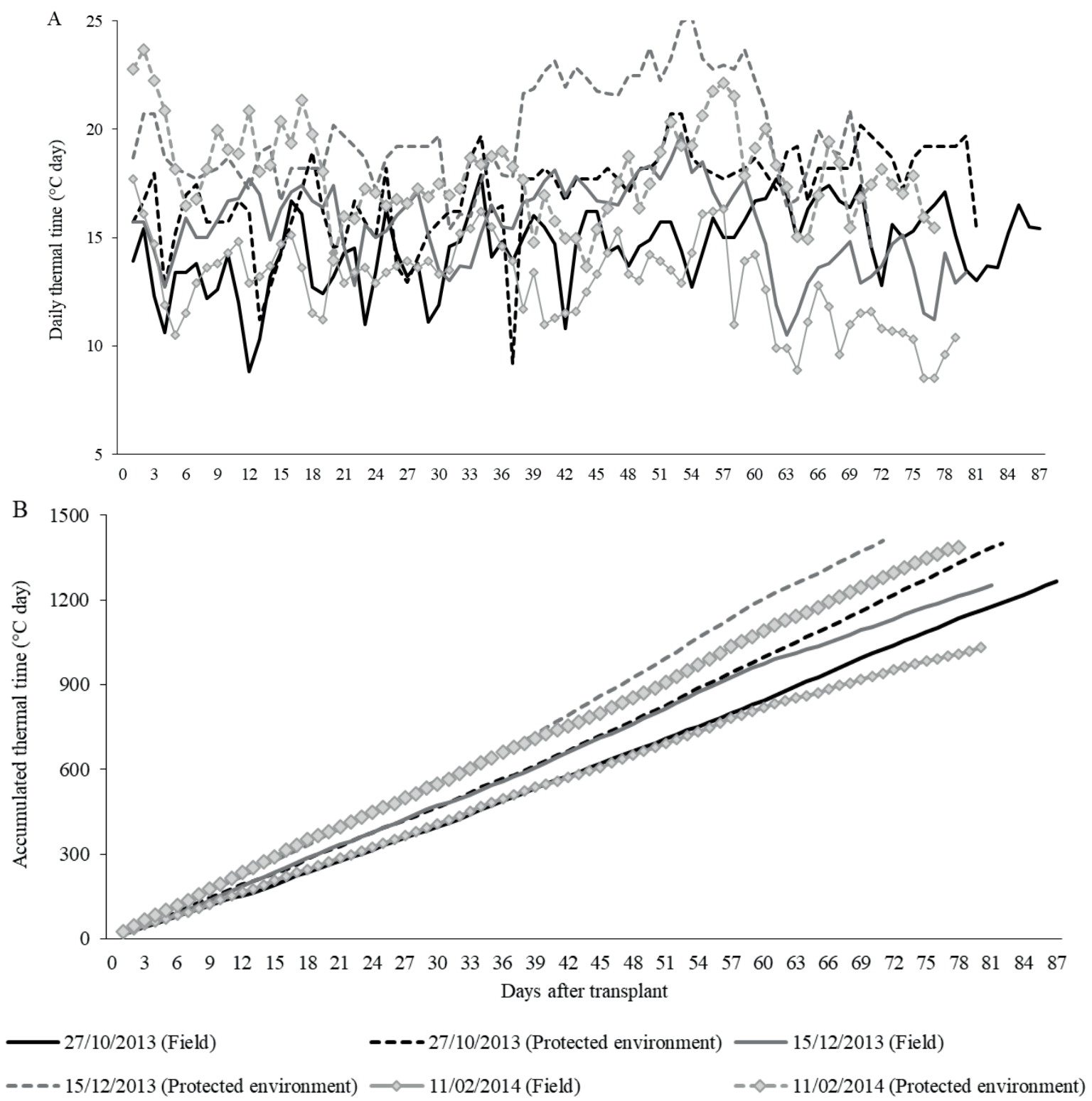

Figure 1. (A) Daily thermal time and (B) accumulated thermal time $\left({ }^{\circ} \mathrm{C}\right.$ day) during the monitoring dates used to estimate the plastochron and the leaf area in Physalis peruviana cultivated in a field and protected environment, in three transplant dates.

At the end of both follow-up periods, by isolated and combined analyses, no differences were found for the number of visible nodes (NN) on the two main stems. The average number of nodes was 9.6 at the beginning of flowering and 31.7 at the beginning of fruit ripening. In this sense, we could observe that $P$. peruviana presented higher emission of nodes in the reproductive stage, hence requiring higher aTS in the time from flowering until fruit ripening.

Regressions between NN in the main stem and aTS for plastochron estimation showed a close relation $\left(R^{2} \geq 0.92\right)$ for combinations of cultivation environment and transplantation time, in both development phases. Values of $\mathrm{R}^{2} \geq 0.92$ show linearity between NN and aTS and the importance 
of air temperature as the main abiotic factor controlling the appearance of nodes in P. peruviana.

The existence of linearity between $\mathrm{NN}$ and aTS demonstrates that the plastochron concept is an adequate method to predict vegetative and reproductive development in $P$. peruviana, as reported in other species such as green beans (Heldwein et al., 2010), soybeans (Streck, Paula, Camera, Menezes, \& Lago, 2008), watermelon (Lucas et al., 2012), and grapevine (Zeist et al., 2016). The increased linearity between NN and aTS found in P. peruviana corroborates Liu and Heins (2002), who stated that thermal energy, through temperature, coordinates vegetative development and growth.
The smallest standard errors in plastochron estimation were obtained when the crop cycle was divided into two distinct phases, between transplanting and beginning of flowering (TR-FL) and from flowering until ripening begins (FL-FR). The values were $\leq 6.4$ on the three transplanting times and in the two crop environments (Figure 2). By contrast, when considered a single time, from transplantation until the beginning of ripening (TR-FR), higher standard errors were obtained $(\mathrm{SE} \geq 8.6)$ for all combinations between times and environments.

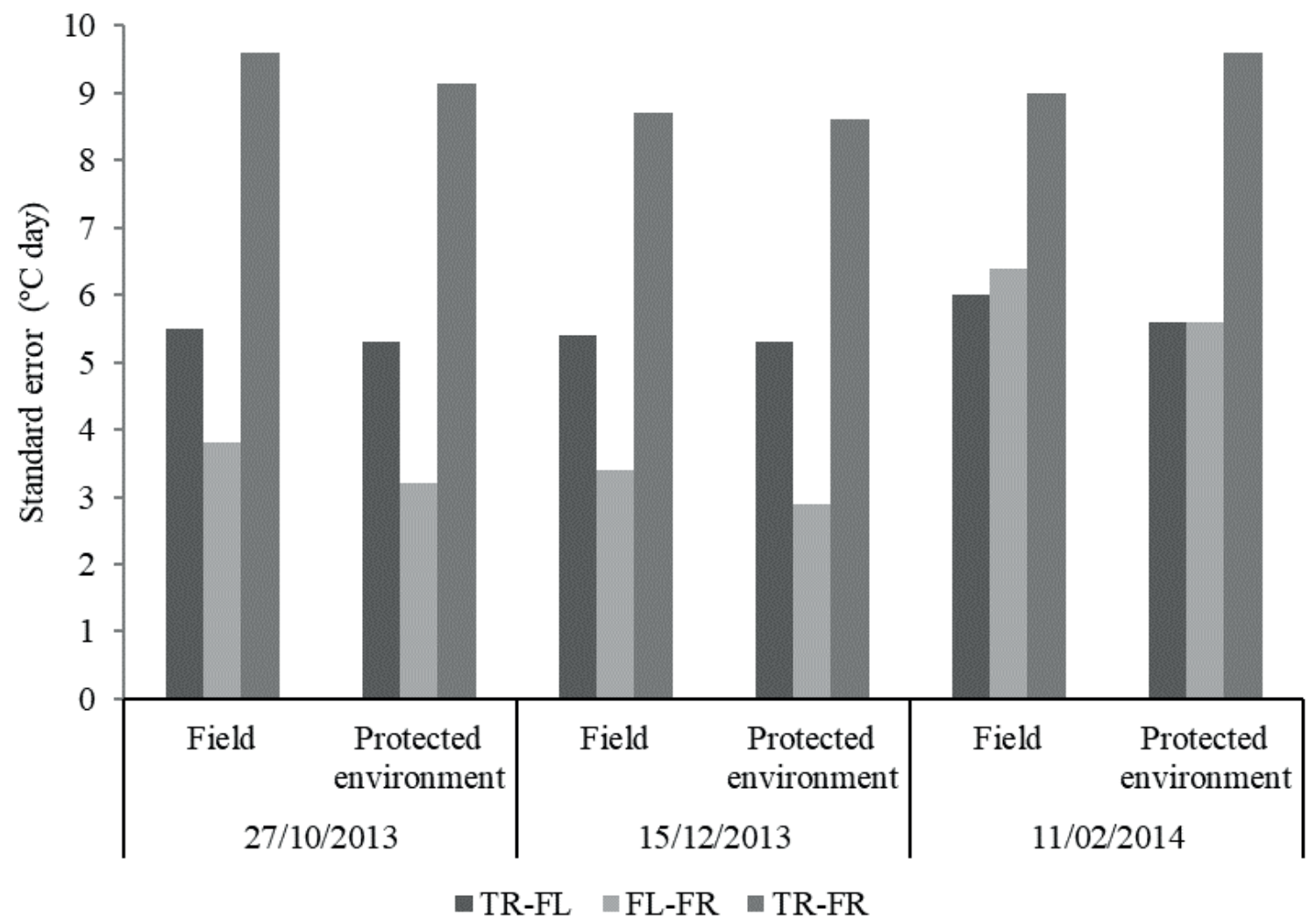

Figure 2. Standard error, obtained from the plastochron in the vegetative phase (TR-FL), reproductive phase (FL-FR) and single phase (TR-FR), in Physalis peruviana cultivated in a field and protected environment, in three transplant periods: 27/10/2013, 15/12/2013 and 11/02/2014. 
Our findings indicate that safe plastochron estimates can be obtained by dividing the $P$. peruviana cycle into vegetative (TR-FL) and reproductive (FL-FR) phases. Similar results were reported by Toebe et al. (2010) when comparing developmental times for plastochron estimation in crambe. These authors observed that root square mean errors (RSME) were lower from emergence to flowering and from flowering to fruiting, thus cramble cycle can be divided into phases for more accurate plastochron estimates.

For the vegetative phase, the joint analysis between cultivation environments and transplanting times showed no significant interaction for plastochron, leaf area (LA), and leaf area/number of nodes (LA/NN) ratio, with mean values of 60.4 ${ }^{\circ} \mathrm{C}$ day node ${ }^{-1}, 974.7 \mathrm{~cm}^{2}$, and 101.5 , respectively. As for isolated analyses, a significant difference was observed only for LA, wherein the protected environment had a larger area (Table 2). This is related to the greater need to intercept light energy, as it reaches the plants in smaller amounts compared to an open environment (Reis, Azevedo, Albuquerque, \& Silva, 2013). 


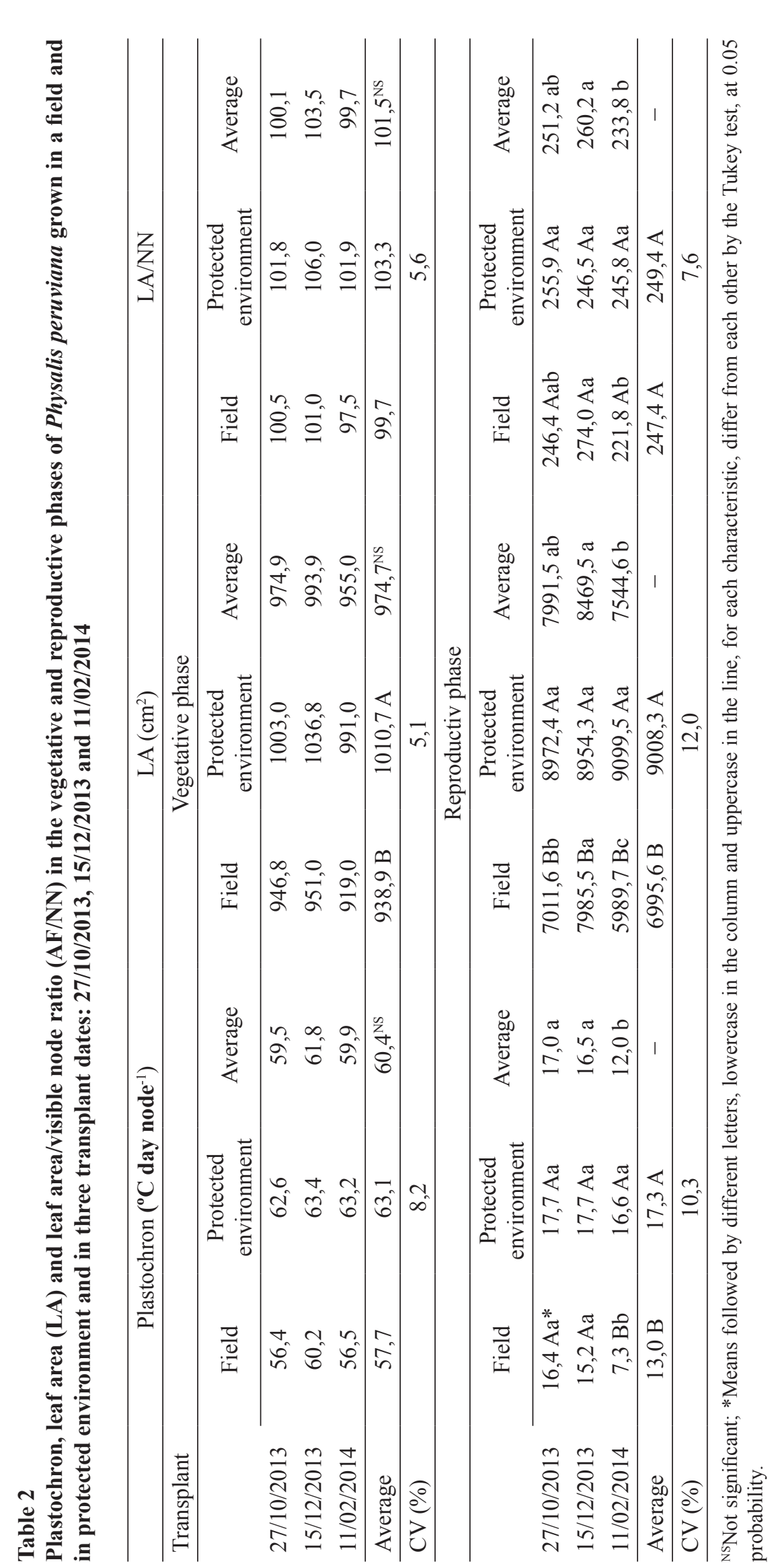


For the reproductive phase, the joint analysis revealed that plants grown in the field crop and transplanted on time $3(02 / 11 / 2014)$ had the lowest plastochron estimate $\left(7.3^{\circ} \mathrm{C}\right.$ day node $\left.{ }^{-1}\right)$. Conversely, the other interactions between environments and times did not differ significantly from each other, with a mean plastochron value of $16.7^{\circ} \mathrm{C}$ day node ${ }^{1}$. There were also higher values of LA and LA/NN ratio in the protected environment on transplantation time $2(10 / 27 / 2013)$ and $3(02 / 10 / 2014)$.

From a biological perspective, dTS can be considered a real-time measure (Streck et al., 2008; Fagundes, Streck, Storck, Reiniger, \& Kruse, 2008). Thus, the lower the estimated plastochron value, the less the plant would need dTS for a successive node appearance in stems. Likewise, Toebe et al. (2010) observed a higher efficiency of node emission by crambe plants as a function of air temperature when comparing reproductive and vegetative phases. The higher emission of nodes during P. Peruviana reproductive phase may be related to the onset of flowers, which needs high emission of nodes in response to air temperature $\left({ }^{\circ} \mathrm{C}\right.$ day node $\left.{ }^{-1}\right)$.

The lower plastochron rate in plants grown in the field and transplanted on 02/11/2014 may be explained by lower temperatures during the reproductive phase of plants. It happens because these plants were transplanted later than the other dates, causing thermal stress and inducing plants to complete their cycle faster, with less aTS, thus reducing their response efficiency to the emission of new nodes due to air temperature.

Although no difference in $\mathrm{NN}$ was observed for plants grown in the field and transplanted on $02 / 11 / 2014$, as a result of lower dTS, seedling vegetative growth and development and yield were compromised. This fact can be proved by lower LA and LA/NN ratio (Table 2), besides reduced fruit number (NCF) and commercial yield (CFY) (Table 3).

Table 3

Number of commercial fruits - (NFC), commercial fruit yield (CFY) and average mass of commercial fruits (AMCF) dof Physalis peruviana grown in a field and in protected environment and in three transplant dates: 27/10/2013, 15/12/2013 e 11/02/2014 27/10/2013, 15/12/2013 and 11/02/2014

\begin{tabular}{|c|c|c|c|c|c|c|c|c|c|}
\hline \multirow[t]{2}{*}{ Transplant } & \multicolumn{3}{|c|}{$\mathrm{NFC}\left(\mathrm{n}^{\circ}\right.$ plant $)$} & \multicolumn{3}{|c|}{ CFY (g plant) } & \multicolumn{3}{|c|}{ AMCF (g fruit) } \\
\hline & Field & $\begin{array}{c}\text { Protected } \\
\text { environment }\end{array}$ & Average & Field & $\begin{array}{c}\text { Protected } \\
\text { environment }\end{array}$ & Average & Field & $\begin{array}{c}\text { Protected } \\
\text { environment }\end{array}$ & Average \\
\hline $27 / 10 / 2013$ & $55,1^{\mathrm{ns}}$ & 89,0 & $72,0 \mathrm{a}$ & 127,1 & 253,2 & $190,1 \mathrm{ab}$ & 2,3 & 2,9 & $2,6 \mathrm{a}$ \\
\hline $15 / 12 / 2013$ & 56,1 & 89,6 & $72,8 \mathrm{a}$ & 130,8 & 265,7 & $198,3 \mathrm{a}$ & 2,3 & 3,0 & $2,7 \mathrm{a}$ \\
\hline $11 / 02 / 2014$ & 42,6 & 86,1 & $64,4 \mathrm{~b}$ & 98,3 & 252,2 & $175,3 \mathrm{~b}$ & 2,3 & 2,9 & $2,6 \mathrm{a}$ \\
\hline Average & $51,2 \mathrm{~B}$ & $88,2 \mathrm{~A}$ & - & $118,7 \mathrm{~B}$ & $257,0 \mathrm{~A}$ & - & $2,3 \mathrm{~B}$ & $2,9 \mathrm{~A}$ & - \\
\hline CV (\%) & & 8,2 & & & 7,6 & & & 12,5 & \\
\hline
\end{tabular}

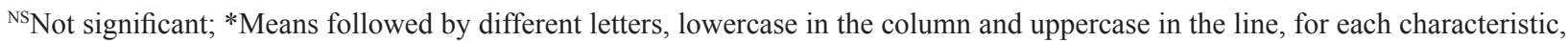
differ from each other by the Tukey test, at 0.05 probability.

As for fruit production, on one hand, no significant interaction was observed between the assessed parameters by joint analysis. On the other, isolated factor analysis showed increases in NCF, CFY, and AMCF for plants grown in the protected environment, and for plants transplanted on 10/27/2013 and 12/15/2013 there were increases in NCF and CFY (Table 3).

LA is a relevant trait because it is indicative of productivity, as photosynthesis depends on light 
interception and its conversion into chemical energy (Dombroski, Rodrigues, Batista, Lopes, \& Lucena, 2011). The higher values of LA, LA/NN ratio, NCF, $\mathrm{CFY}$, and $\mathrm{AMCF}$ found in the protected environment on the three transplantation dates demonstrate that such environment could improve conditions for $P$. peruviana vegetative development and growth, as well as its fruit production.

According to Moura et al. (2016a), protected environments enable partial control of edaphoclimatic conditions, favor fruit quality, reduce the use of chemical pesticides, and allow cultivation at some times of the year when field cultivation cannot be performed. The same aspect was confirmed by Cecco, Klosowski, Silva and Villa (2018), who compared early growth of Physalis ixocarpa Brot. and Physalis minima L. in a greenhouse, under $50 \%$ shaded roof, and in open field.

The lower values of LA, LA/NN ratio, $\mathrm{NCF}$, and CFY obtained in the field on 02/11/2014 demonstrate that not all dates are suitable for transplanting $P$. peruviana in the field for the region of GuarapuavaPR. Therefore, late seedling transplantation (late summer) is not recommended, i.e., in February.

Since, until now, there was no scientific evidence of biological time $\left({ }^{\circ} \mathbf{C}\right.$ day node $\left.{ }^{-1}\right)$ for P. peruviana, we recommend using plastochron values of $60.0^{\circ} \mathrm{C}$ day node $^{-1}$ for vegetative and about $16.5^{\circ} \mathbf{C}$ day node $^{-1}$ for reproductive phases, as references for regions with similar climates to that of the region under study.

When a crop cycle is within the recommended season, i.e. under ideal temperature conditions for development, thermal energy falls within the range of linear response of plant development (Streck et al., 2005; Lucas et al., 2012). Thus, using thermal sum as a representation of biological time in plants is a more realistic and widely used method, which generally improves prediction of the dates of plant development stages (Streck et al., 2005).
Indeed, our findings on P. peruviana plastochron, growth and vegetative development, and yield are of interest to farmers and can serve as a basis for further studies on adaptation and establishment of plants in new areas and on different times for $P$. peruviana production. Such information can be used to suggest developmental stage durations, predict fruit ripening onset, and select the best time and environment for seedling transplanting.

\section{Conclusion}

In both field and protected environments, plastochron values of 60.0 and $16.5^{\circ} \mathrm{C}$ day node ${ }^{-1}$ can be used for Physalis peruviana during vegetative and reproductive development phases, respectively.

Protected environments provide greater vegetative growth and development and productivity if compared to field cultivation.

Among the studied times, $P$. peruviana transplanting in the Guarapuava region must be carried out by December to ensure great fruit yield and quality.

\section{References}

Araújo, H. F., Leal, P. A. M., Zorzeto, T. Q., Nunes, E. F., Betin, P. S., \& Servilha, G. F. P. (2016). Alterações micrometeorológicas em ambientes protegidos cultivados com minitomate orgânico. Irriga, 21(2), 226-238. doi: 10.15809/irriga.2016v21n2p226-238

Arnold, C. Y. (1960). Maximum-minimum temperatures as a basis for computing heat units. Proceedings of the American Society for Horticultural Sciences, 76(1), 682-692.

Cecco, R. M., Klosowski, E. S., Silva, D. F., \& Villa, F. (2018). Germinação e crescimento inicial de mudas de espécies não convencionais de fisális em diferentes substratos e ambientes. Revista de Ciências Agroveterinárias, 17(1), p.45-53. doi: $10.5965 / 223811711712018045$

Coletti, R., Nienow, A. A., \& Calvete, E. O. (2011). Superação da dormência decultivares de mirtileiro em ambiente protegido com cianamida hidrogenada e óleo mineral. Revista Brasileira de 
Fruticultura, 33(2), 685-690. doi: 10.1590/S010029452011005000054

Dombroski, J. L. D., Rodrigues, G. S. O., Batista, T. M. V., Lopes, W. A. R., \& Lucena, R. R. M. (2010). Análise comparativa de métodos de determinação de área leaf em pinha (Annona Squamosa L.). Revista Verde, 5(3), 188-194. doi: 10.18378/rvads.v5i3.322

Empresa Brasileira de Pesquisa Agropecuária (2013). Centro Nacional de Pesquisa de Solos. Sistema brasileiro de classificação de solos (3a ed.). Rio de Janeiro: EMBRAPA CNPS.

Fagundes, J. D., Streck, N. A., Storck, L., Reiniger, L. R. S., \& Kruse, N. D. (2008). Temperatura base, plastocrono e número final de nós no malmequerdo-campo. Ciência Rural, 38(9), 2471-2477. doi: $10.1590 / \mathrm{S} 0103-84782008005000021$

Fischer, G., Almanza-Merchán, P. J., \& Miranda, D. (2014). Importancia y cultivo de la Uchuva (Physalis peruviana L.). Revista Brasileira de Fruticultura, 36(1), 1-15. doi: 10.1590/0100-2945-441/13

Heldwein, A. B., Streck, N. A., Sturza, V. S., Loose, L. H., Zanon, A. J., Toebe, M.,... Karlec, F. (2010). Plastocrono e rendimento de feijão-de-vagem cultivado sob ambiente protegido e no ambiente externo em semeadura tardia no outono. Ciência Rural, 40(4), 768-773. doi: 10.1590/S010384782010005000045

Koetz, M., Carvalho, J. A., Sousa, A. M. G., \& Souza, K. J. (2010). Qualidade de frutos do maracujazeiroamarelo em ambiente protegido e natural produzidos sob diferentes regimes de irrigação. Revista Brasileira de Agricultura Irrigada, 4(2), 115-126.

Lagos, T. C. B., Valejo, F. A. C., Criollo, H. E., \& Muñoz, J. E. F. (2008). Biología reproductiva de la uchuva. Acta Agronómica Colombiana, 57(2), 81-87.

Licodiedoff, S., Ribani, R. H., Camlofski, A. M. O., \& Lenzi, M. K. (2013). Use of image analysis for monitoring the dilution of Physalis peruviana pulp. Brazilian Archives of Biology and Technology, 56(3), 467-474. doi: 10.1590/S1516-89132013000300015

Lima, C. S. M., Gonçalves, M. A., Tomaz, Z. F. P., Rufato, A. R., \& Fachinello, J. C. (2010). Sistemas de tutoramento e épocas de transplante de physalis. Ciência Rural, 40(12), 24722479. doi: 10.1590/ S0103-84782010001200006

Lima, C. S. M., Manica-Berto, R., Silva, S. J. P., Betemps, D. L., \& Rufato, A. R. (2009). Custos de implantação e condução de pomar de Physalis na região sul do estado do Rio Grande do Sul. Revista Ceres, 56(5), 555-561.
Liu, B., \& Heins, D. (2002). Photothermal ratio affects plant quality in 'Freedom' Poinsettia. Journal of the American Society for Horticultural Science, 127(1), 20-26.

Lucas, D. D. P., Streck, N. A., Bortoluzzi, M. P., Trentin, R., \& Maldaner, I. C. (2012). Temperatura base para emissão de nós e plastocrono de plantas de melancia. Revista Ciência Agronômica, 43(2), 288-292.

Martins, J. D., Carlesso, R., Petry, M. T., Knies, A. E., Oliveira, Z. B., \& Broetto, T. (2012). Estimativa do filocrono em milho para híbridos com diferentes ciclos de desenvolvimento vegetativo. Ciência Rural, 42(5), 777-783. doi: 10.1590/S010384782012000500003

Mendoza, J. H., Rodriguez, A., \& Millan, P. (2012). Caracterización físico química de La Uchuva (Physalis peruviana) em La Région de Silvia Cauca. Revista Bioagro, 10(2), 188-196.

Moraes, L., Santos, R. K., Wisser, T. Z., \& Krupek, R. A. (2013). Avaliação da área leaf a partir de medidas lineares simples de cinco espécies vegetais sob diferentes condições de luminosidade. Revista Brasileira de Biociências, 11(4), 381-387.

Moura, P. H. A., Coutinho, G., Pio, R., Bianchini, F. G., \& Curi, P. N. (2016a). Plastic covering, planting density, and prunning in the production of cape gooseberry (Physalis peruviana L.) in Subtropical Region. Revista Caatinga, 29(2), 367-374. doi: 10.1590/1983-21252016v29n213rc

Moura, P. H. A., Pio, R., Curi, P. N., Rodrigues, L. C. A., Bianchini, F. G., \& Bisi, R. B. (2016b). Cobertura plástica e densidade de plantio na qualidade das frutas de Physalis peruviana L. Revista Ceres, 63(3), 334-339. doi: 10.1590/0034-737X201663030009

Muniz, J., Kretzschmar, A. A., Rufato, L., Pelizza, T. R., Marchi, T., Duarte, A. E.,... Garanhani, F. (2011). Sistemas de condução para o cultivo de Physalis no Planalto Catarinense. Revista Brasileira de Fruticultura, 33(3), 830-838. doi: 10.1590/S010029452011005000083

Pereira, L. C., Campelo, J. H., Jr., \& Ferronato, A. (2010). Comparação de métodos para estimativa do plastocrono em algodoeiro em condições tropicais. Pesquisa Agropecuária Tropical, 40(2), 213-220. doi: $10.5216 /$ pat.v40i2.6716

Picolotto, L., Pereira, I. S., Vignolo, G. K., Reisser, C., Jr., \& Antunes, L. E. C. (2014). Quebra de dormência e cultivo protegido na produção de plantas de mirtileiro. Revista Brasileira de Fruticultura, 36(1), 271-278. doi: 10.1590/0100-2945-247/13 
Reis, L. S., Azevedo, C. A. V., Albuquerque, A. W., \& Silva, J. F., Jr. (2013). Índice de área leaf e produtividade do tomate sob condições de ambiente protegido. Revista Brasileira de Engenharia Agricola e Ambiental, 17(4), 386-391. doi: 10.4025/ actasciagron.v38i2.27893

Salazar, M. R., Jones, J. W., Chaves, B., Cooman, A., \& Fischer, G. (2008). Base temperature and simulation model for nodes appearance in cape gooseberry (Physalis peruviana L.). Revista Brasileira de Fruticultura, 30(4), 862-867. doi: 10.1590/S010029452008000400004

Silva, D. F., Villa, F., Barp, F. K., Rotili, M. C. C., \& Stumm, D. R. (2013). Conservação pós-colheita de fisális e desempenho produtivo em condições edafoclimáticas de Minas Gerais. Revista Ceres, 60(6), 826-832. doi: 10.1590/S0034737X2013000600011

Silva, F. A. S., \& Azevedo, C. A. V. (2016). The Assistat Software Version 7.7 and its use in the analysis of experimental data. African Journal of Agricultural Research, 11(39), 3733-3740. doi: 10.5897/ AJAR2016.11522

Streck, N. A., Paula, G. M., Camera, C., Menezes, N. L., \& Lago, I. (2008). Estimativa do plastocrono em cultivares de soja. Bragantia, 67(1), 67-73. doi: 10.1590/S0006-87052008000100008

Streck, N. A., Tibola, T., Lago, I., Buriol, G. A., Heldwein, A. B., Schneider, F. M., \& Zago, V. (2005). Estimativa do plastocrono em meloeiro (Cucumis melo L.) cultivado em estufa plástica em diferentes épocas do ano. Ciência Rural, 35(6), 1275-1280. doi: $10.1590 / \mathrm{S} 0103-84782005000600008$
Taiz, L., \& Zeiger, E. (2013). Fisiologia vegetal (5a ed.). Porto Alegre: Artemed.

Toebe, M., Lopes, S. J., Storck, L., Silveira, T. R., Milani, M., \& Casarotto, G. (2010). Estimativa de plastocrono em crambe. Ciência Rural, 40(4), 793799. doi: 10.1590/S0103-84782010005000054

Tomazetti, T. C., Rossarolla, M. D., Zeist, A. R., Giacobbo, C. L., Welter, L. J., \& Alberto, C. M. (2015). Fenologia e acúmulo térmico em videiras viníferas na região da Fronteira Oeste do Rio Grande do Sul. Pesquisa Agropecuária Brasileira, 50(11), 10331041. doi: 10.1590/S0100-204X2015001100006

Wrege, M. S., Steinmetz, S., Reisser, C., Jr., \& Almeida, I. R. (2011). Atlas climático da Região Sul do Brasil: Estados do Paraná, Santa Catarina e Rio Grande do Sul (21a ed.). Pelotas: EMBRAPA Clima Temperado; Colombo: EMBRAPA Florestas.

Zeist, A. R., Alberto, C. M., Tomazetti, T. C., Rossarolla, M. D., Giacobbo, C. L., \& Welter, L. J. (2016). Plastochron estimate in grapevine 'Marselan' and 'Tannat' cultivars. Cientifica, 44(4), 471-476. doi: 10.15361/1984-5529.2016v44n4p471-476

Zeist, A. R., Tomazetti, T. C., Rossarolla, M. D., Alberto, C. M., Giacobbo, C. L., \& Welter, L. J. (2017). Plastochron index of 'Cabernet Sauvignon' and 'Chardonnay' grapevines in Fronteira Oeste, in the state of Rio Grande do Sul, Brazil. Pesquisa Agropecuária Brasileira, 52(4), 244-251. doi: 10.1590/s0100-204x2017000400004 